\title{
Adult Sickle Cell Quality of Life Measurement Information System
}

National Cancer Institute

\section{Source}

National Cancer Institute. Adult Sickle Cell Quality of Life Measurement Information

System. NCl Thesaurus. Code C154481.

A patient-reported outcome measurement system designed to evaluate and monitor the physical, mental, and social well-being of adults with sickle cell disease. 